\title{
Trust Based Relationships between Family Members and Long-Term Employees of Family-Owned SMEs
}

\author{
Ferda Erdem ${ }^{1} \&$ Nuray Atsan ${ }^{1}$ \\ 1 Department of Business Administration, Faculty of Economics and Administrative Sciences, Akdeniz \\ University, Antalya, Turkey \\ Correspondence: Ferda Erdem, Department of Business Administration, Faculty of Economics and \\ Administrative Sciences, Akdeniz University, Antalya, Turkey. Tel: 90-242-310-1843. E-mail: \\ ferdem@akdeniz.edu.tr
}

Received: February 24, 2015

Accepted: March 14, 2015

Online Published: March 25, 2015

doi:10.5539/ibr.v8n4p223

URL: http://dx.doi.org/10.5539/ibr.v8n4p223

\begin{abstract}
The purpose of this study is to identify dimensions of trust between family members in family-owned SMEs and long-term non-family employees who have been working in the enterprise with at least two generations. The data of the study were collected through interviews with the second generation members actively working in ten family businesses that operate in different sectors. The thematic analysis of the interview notes revealed that the dimensions of trust of family members in non-family employees included competence, identification and personal trustworthiness. Competence of the non-family employees means that they possess the practical skills to tackle various issues related to the family and enterprise. Identification of the long-term employees with the enterprise refers to the content that can be explained with the protection of the interests of the family and enterprise, self-commitment, and adaptation to the values. This is interpreted as psychological ownership. Trustworthiness, on the other hand, points to the ethical conduct such as truthfulness and contentedness. These findings show that trust in the non-family employees who have been working in family-owned SMEs has a specific context. Suggesting some implications for future studies, the findings also contain evidence demonstrating that the family business is a strong niche for scholars studying organizational behavior.
\end{abstract}

Keywords: family business, SMEs, trust, non-family employees, family members, psychological ownership

\section{Introduction}

Family business is the most common business organization form throughout the world and nearly all firms started as family-owned businesses (Lee, 2006, p. 103). Although the ratio of the family-owned businesses to the total business population in the world varies across different countries, it is estimated to range from $65 \%$ to $90 \%$ (Sharma, Chua, \& Chrisman, 2000, p. 233). The majority of these enterprises are small and medium sized. Their structural and behavioral characteristics, strategic orientations, cultural features, environmental relationships, sustainability efforts make them interesting for both academicians and practitioners. Gagné, Sharma and DeMassis (2014) drew attention to the consensus among scholars that these firms are conceptually and qualitatively different from non-family firms due to the influence of family members and kinship ties on the enterprise (p. 643). Sharma, Chrisman, and Chua (1997) stated that family businesses may differ from non-family businesses because the controlling family's influence, interests, and values have overriding importance (p. 4).

In terms of new knowledge potential, business formation, growth and expansion, professionalizing, strategic management, and succession are central themes in family business research (Bhat, Shah, \& Baba, 2013). However, there are many other phenomena concerning family businesses that are yet to be discovered by researchers. Campopiano, DeMassis, and Chirico (2014) noted that some important issues and topics related to such businesses have only been marginally studied (p. 244) and (Bhat et al., 2013) stated that few aspects are known about the differences between large and small sized family businesses. Gagné et al. (2014) find it surprising that scholars studying organizational behavior have not paid attention to family businesses. Moreover, Sharma and Carney (2012) indicated that the subjects specific to the family-owned businesses offer opportunities to develop original theories. They explained that family businesses have got the potential because they have the capacity to develop intangible assets such as social capital, trust and tacit knowledge, but there are a limited 
number of studies on these topics due to measurement difficulties (p. 234). Recently, some researchers have also underlined this issue. For example, Rafaeli (2013) argued that the emotional aspects in family-owned businesses are not known adequately. Bee and Neubaum (2014) drew attention to the fact that the context of family businesses provide researchers with opportunities; as a matter of fact, one of the research questions they suggest is whether the emotions that non-family managers experience are different from the emotions that managers in non-family businesses experience (p. 331).

Family business is one of the most powerful forms of social capital; however, it has still not received the attention it deserves. In fact, it is possible to see that the issue of trust is often mentioned when stewardship and agency theories are adapted to family businesses (Henssen, Voordeckers, Lambrechts, \& Koiranen, 2014). Nonetheless, lack of studies focusing directly on trust relationships in the specific context of these businesses is strongly felt. Particularly, trust may be a key variable to understand different aspects of relationships between the family members and non-family members. Some non- family employees have been in the business working with family members from several generations; these employees have witnessed the history of the family and the business. Hence, this situation cannot be explained through a stable employment policy; probably there are strong special trust relationships between the parties.

\section{Trust in Family Businesses}

Trust in interpersonal relationships occurs when either of the parties expects the other party not to do harm to or abuse himself/herself (Rousseau, Sitkin, Burt, \& Camerer, 1998) and it has cognitive and affective foundations (McAllister, 1995). Cognitive trust is based on beliefs about competence, integrity, responsibility, credibility, reliability, and dependability (Ribiere \& Sitar, 2010, p. 39). However, trust is not only thought but also felt (Kramer, 1999, p. 572); affective trust is built in emotional bonds and parties believe that these sentiments are reciprocated (McAllister, 1995, p. 26). This structure of trust includes the dimensions of benevolence, being interested, loyalty, altruism, commitment, and mutual respect (McAllister, 1995; Mayer, Davis, \& Schoorman, 1995; Davis, Schoorman, Mayer, \& Tan, 2000; Jarvenpaa, Shaw, \& Staples, 2004; Ribiere \& Sitar, 2010). In the case of long-term relationships, parties feel committed to each other, which can be explained through empathy and this eventually leads to unconditional trust. In the case of unconditional trust, sense of mutual identification develops (Jones \& George, 1998). Moreover, cognitive and affective trust can be related to each other; the relationship starts from perceived cognitive trust and it can be transformed through experiences into affective trust (Erdem \& Özen, 2003, p. 131). McAllister (1995) emphasizes that some level of cognition-based trust may be necessary for affect-based trust to develop (p. 30).

As family businesses have more complicated emotional dynamics than other businesses do (Rafaeli, 2013), trust and loyalty distinguish such businesses from others (Eddleston, Chrisman, Steier, \& Chua, 2010; Sundaramurthy, 2008; Eddleston \& Morgan, 2014). According to Sundaramuthy (2008), family business is a dynamic beyond economic rationality, and trust is a fundamental value for such businesses (p. 89). Carlock and Ward (2001) argue a family business makes valuing trust and creating a trusting environment the foundation of their planning and management systems (p. 11), and trust becomes progressively family's capital.

Gagné et al. (2014) claim that the factors influencing trust may vary since family and non-family members have different relationships that are based on different norms. In fact, often harmony or disagreement between family members and non-family employees may arise directly because of a trust problem. For example, nepotism is an important reason for distrust of non-family employees. Keleş, Özkan, and Bezirci (2011) found out in their study that nepotism, favoritism and cronyism reduce organizational trust in family businesses (p. 10). On the other hand, family members who think non-family members are not strongly loyal to the business are unwilling to empower them due to lack of confidence.

Despite these general remarks, we cannot find an analysis regarding the details of a strong trust relationship between family and non-family members. Debates concerning the employment of outsiders for management positions in large-sized family businesses and reduction of their agency costs may be related to the trust issue (Blumentritt, Keyt, \& Astrachan, 2007). However, the studies in the literature have not sufficiently focused on trust relation between the family members and non-family employees in small businesses, where informal interactions are much stronger and which are more vulnerable to local cultural codes. Nonetheless, some employees can work in such businesses for a very long time, and are in harmony with the family members; except the categories of family members and non-family members, they constitute the third type that can be defined as semi-family membership. They have a commitment to the founder/owner and also to the family (Gagné et al., 2014), and this strong posture provides a distinctive feature to them both within the business and the family. 
The aim of this study to clarify which characteristics and behaviors of non-family employees in SMEs enable the family members to trust them. The findings of this research on older non-family employees in family businesses may contribute to the understanding of some behavioral dynamics in the context of SMEs.

\section{Method}

In this research, which was designed according to the qualitative method, face-to-face interviews were held with 10 second generation family members (4 female and 6 male) who accepted to participate in the research. The participants were from 10 enterprises in different sectors (trade, manufacturing and service) in Antalya. The authors asked them the following question: "Which characteristics of your long-standing employees who have been working with the $1^{\text {st }}$ and $2^{\text {nd }}$ generation of the family for minimum fifteen years make you trust them?" The participants were asked to share their observations, experiences, and also previous generations' experiences regarding the senior employees working for the enterprise with two generations. Then, the interview notes were transcribed and thematic analysis was performed. The main dimensions and contents of trust of family members in long-term employees were, thus, revealed.

\section{Findings}

The participants explained in the beginning of the interviews that there is more than one non-family employee who has been working there for minimum fifteen years. However, all participants were observed to highlight mainly one specific long-standing employee during the interviews and shared their experiences with and observations about that employee indepth. The researchers did not intervene in this situation, and considered this spontaneous preference as an interesting finding of the research.

The family-members participating in the study and representing the second generation first have stated that their long-standing non-family employees have a good command of many processes in the enterprise, facilitate these processes for everyone in the enterprise and they are problem solvers. These employees have full knowledge of all events related to the business and family. Particularly they find quick solutions to the problems of family members and of the business and they function as facilitators. This competence makes them indispensable for the family and business:

“... they are like $24 / 7$ back-up ... They are the first to come to my mind whenever I face a problem ... I call them whenever my car breaks, and whenever I cannot find my keys ..." (n. 2)

On the other hand, they also indicated that the non-family employees mentioned in all interviews protect not only the interests and important resources of the business but also the family from other groups (internal or external). They have always stood by the side of family members throughout all the challenging times since the establishment of the enterprise. They have not even abandoned the enterprise despite the better job opportunities they have been offered outside; they have always remained loyal and faithful. This points to the fact that the non-family employees identify themselves with the family and enterprise:

"... they have always been here, so we are like a family after all these years together. Both we and they feel as if we were a family: A relationship close-knit ... (6)

"... these people live with us.. in good times and bad times, they back us not only for the business-related matters but also to share our happiness and sadness!"(7)

“... they ensure the sustainability of the culture by isolating those who are not in harmony with the culture of our business ..." (1)

The family members thought that all these traits of non-family employees they mentioned under the scope of competence and identification are associated with their personal trustworthiness: Integrity, decency, honesty, contentedness and sincerity of these employees make them trustworthy in the eyes of family members. Family members can entrust their enterprise to these non-family employees without any concern and without any doubt:

“... he is personally very trustworthy ... my father confirms all information in the enterprises by asking his point of view ... he has never disappointed us! ...” (3)

“... he is very contented! ..." (1)

“... I trust him so much that he can go our home and grab the required document from any drawer!”

In summary, the findings we obtained show that the main dimensions of trust of family members in non-family employees in a family business are competence, identification and personal trustworthiness. Table 1 presents all findings collectively including the dimensions, contents of trust and characteristic verbatim from interview notes. 
Table 1. Trust in non-family members/employees

\begin{tabular}{|c|c|c|}
\hline Dimension of Trust & Contents & Verbatim Examples \\
\hline Competence & $\begin{array}{l}\text { Being } \\
\text { knowledgeable of } \\
\text { many jobs, being } \\
\text { a problem-solver } \\
\text { and getting things } \\
\text { in order, } \\
\text { hardworking, } \\
\text { being disciplined, } \\
\text { finding quick } \\
\text { solutions to the } \\
\text { problems of } \\
\text { family and firm, } \\
\text { facilitation }\end{array}$ & $\begin{array}{l}\text {....They assume responsibility for many things that are not defined in their terms of reference ...for } \\
\text { example, they settle down many issues inside and outside the company although they are at } \\
\text { advanced age ... they complete the tasks on time, they do not deal with their private issues in the } \\
\text { meantime ...(1) } \\
\text {....They don't have a certain job definition; he tackles the business whenever my father needs } \\
\text { someone trustworthy, someone to entrust the company with and whenever he is outside the } \\
\text { company...(2) } \\
\text {....whenever my father is out, nearly all powers are granted to him ...of course my father is } \\
\text { informed about all processes in the shop and all decisions to be taken while he is out of the shop, } \\
\text { but we usually leave the things to him ....he will take the right decision anyway (3) } \\
\text {....he worked in all departments in the factory. Now the cash box of my company is entrusted to } \\
\text { him.(4) } \\
\text { They have written job definitions. In addition to that, if there is something to be done although it is } \\
\text { not in his job definition, he does not hesitate to settle it down as he thinks it has to be done(5) } \\
\text {..they have high job performance, they are disciplined ...(6) } \\
\text {..for example, they sell, executes the sale transaction at the public notary. He transports cash from } \\
\text { one bank to another...ever since I could remember, he has been here. He was the one who used to } \\
\text { take me from school when I was a kid and now he is still the one who sells and executes the bank } \\
\text { transactions....(7) } \\
\text {...our company is challenging, we never stop...we always have a story and we demand many } \\
\text { things from our employees, he is the one who can always meet these demands! (8). } \\
\text {..we hire day watchman to prevent robbery, but he sometimes says he can come if we cannot find } \\
\text { anyone for day watchman position! And never leaves the construction side unattended.. (9) } \\
\text {.. he knows everything about the production process; where the machines will be settled, where the } \\
\text { raw materials will come from, where they will go, how the flow will be...this knowledge of him } \\
\text { makes us efficient ...(10) }\end{array}$ \\
\hline
\end{tabular}

..he protects all resources of the company (materials etc.), has eyes only for them, he warns the other staff members about this matter ....(1)

..he checks if things are done accurately at the company ...whenever he finds something wrong, he warns the other staff members... he feels as if he was from the family ...(2)

Everyone left the company in hard times, but this foramen was always with us. He always protected and took care of our interests against the others. But I remember the times when he was not paid for months (3).

Protecting the They are in harmony with the company's culture ...In fact, those who do not adapt to the culture company's leave the company in short time ....(4)

interests,

important

....at a certain point after many years, they assume the ownership of the company more than we do.

For example, if a storm breaks out at night and rained cats and dogs, he comes to the company and turns off the alarm, checks if there is any damage and then goes back home (5)

I think they are very loyal. From my perspective, sometimes I put myself into their shoes and ask myself if I would work at the company as long as they did. I think they feel attached. They embrace the company to a great extent. ... for example, he knows the company's history because he has been in that history ... he tells the history to the new staff members ...(6)

As we have been working with him for a very long time, our code of conduct is their code of conduct. I even think their code of conduct has reflections on our code of conduct. ..(7)

...he was assigned to a very minor post, but now he knows all our price lists, they know our temper ...It means they belong to this enterprise...(8)

...he doesn't hesitate to perform the tasks although they are not specified in his job definition... he makes sacrifices if required by the business (9)

.. the company's affairs are above all other things for him, he does not even give time off to employees unless they have important excuses (10) 
....they both do their job well and they are honest, trustworthy, altruist... (1)

They haven't done anything to betray our trust for so many years...otherwise it wouldn't last so long, they neither did something behind our back nor did they steal any money from us. If they had wanted, they could have done so because they carry lots of money ....For example, if I give him 100 liras to buy something, he gives me back 5 liras if he spends 95 liras of it ...(2)

...my father gives the credit card to him for his spending, he can do anything he wants, but he spends only as much as he needs ... he is trusted fully.(3)

He has the keys of my cash box, but he does not mind being inspected. When he is inspected, he

Honesty, truthfulness,

Trustworthiness frankness, sincerity, contentedness can give a report, give an account; when he makes a mistake, he can admit it, he is an exemplary fellow companion... (4).

I trust him so much that I can give the key of the cash box to him ....In all these years, he has never abused it (5)

We have never seen anything he did to betray our trust. We've never experienced anything like cheating, corruption and as such .....(6)

Trust between us has been tested for many times...they managed to get through such tests.(7)

...I have never heard him saying that his salary is not enough...(8)

...we have tested them many times sometimes without being noticed and sometimes explicitly, we have never observed any abuse (9)

...Colloquially, he does an errand. If the car is to be sent for technical inspection, he can go, we entrust him with our keys and everything. He has never abused us. He works as if he were our hand. (10)

Furthermore, the second generation family members participating in the research strongly emphasized that long-standing employees have always been rewarded by the founders and all family members for their loyalty and faithfulness and they have always been protected by the family. The family members give close attention to their needs and problems because they consider them as part of the family:

“... we know all their families and characteristics. Their problems and needs are observed closely; their needs, if any, are met ... we are like a family here ... (1)

"his daughter and nephew also work with us ... I recently heard something interesting: they used my father's car as the wedding car for his brother, ... (2)... among all employees, he's like a family member ... they call my dad grandfather ... and I call him uncle ...

“... I think my father was like an older brother and father to him.... we even feed the rabbit at the enterprise that his kid could not feed at home... He's like someone from the family (3)

“... they are my family ... we see each other more than we see our spouses or kids ... I note on my agenda and follow their special days (4)

"We have a sort of family setting here ... We have a team that gets the ownership of our business more than we do ... These employees think this enterprise is an assurance for them. I mean, they have the perception that when something bad happens to them, the enterprise will back them ... (5)

"We know their families; we come together on special days like weddings and funerals. ... We don't see each other at weekends ...but we have a warm relationship, we are like a family ... the reason why they work with us for so long is because my father has a humanist attitude ... he values them ... (6)

"... they have been working here since the time of my grandfather ... we know their families ... we know where they live, their mothers, fathers, pedigrees. ... I mean, they are like family members. (7)

... I'm like brother to the employees (10)

However, it was understood that the informal and close relationships between the family members and non-family employees are restricted to the relationships within the enterprise. These relationships do not turn into sincerity or friendship relation that can be maintained outside the enterprise:

“... we have limited interaction outside; ... because otherwise it would be perceived as inequality by other employees or they may have a different self-perception...” (1) 
“... we have an edge when it comes to visits at home ...” (3)

"I try not to miss their weddings, funerals and births but other than that I try to avoid family visits." (4)

“... we don't live inseparably outside. We don't have that kind relationship in the sense of socializing outside, visiting families at home" (5)

“... we come together on special days. But we don't meet at weekends or at another time” (6)

... No, we don't see each other outside. At least I don't like such things. But when there is a funeral or wedding, we pay a visit to them. (9)

“... We definitely visit them on their happy days, sad days to share their feelings. However, we don't see each other outside with the whole family members" (10)

According to all findings, trust relationship between family members and non-family employees in small and medium sized family businesses develop and mutually get stronger in the course of time. Family members trust their long-standing employees and similarly the employees trust the family. This relationship, which has a long history, gradually turns into mutual loyalty with a strong emotional content and informal relationships are usually protected by the boundaries of business.

\section{Discussion and Conclusion}

Family-owned businesses are organizations that generate a specific behavioral pattern because the economic and social structures are intertwined. Sieger, Bernhard, and Frey (2011) refer to many studies and state that family-owned businesses are often known for characteristics such as paternalistic-autocratic rule, founder-centric cultures, lack of delegation, in-group and out-group perceptions of non-family employees, altruism, and nepotism (p. 78). These characteristics distinguish family businesses from non-family businesses. Since the family members are in the owner or employee positions, they are subject to an organizational culture where family and business values are fused. Particularly the small and medium sized family businesses have a strong informal structure, flexible business practices, lower formalization levels (Kok, Uhlaner, \& Thurik, 2003), which differentiate them from not only non-family businesses but also large sized family businesses with respect to their emotional and social codes. Zellweger and Astrachan (2008) stated that in collectivist cultures owners display higher levels of emotional value than owners in individualistic cultures (p. 356). Furthermore, Lee (2006) found out that parentalism is often extended to nonfamily employees, promoting a sense of stability and commitment to the enterprise among all employees (p. 105).

LaChapelle and Barnes (1998) argue that high trust relationship with non-family employees is a requirement for the performance and sustainability of the enterprise. Jimenez, Martos, and Jimenez (2015) assert that there is higher trust, participation and better business climate in family businesses as they have better social relations than the other enterprises. They consider these elements as the determinants of the organizational harmony. Most of the time, the reputation and trustworthiness of the founder also influence the internal and external trust perceptions about the enterprise. The content of trust varies in this type of enterprises across relationships between the family members and staff; enterprise and the suppliers; customers and the other environmental actors. It also plays a critical role in succession. Despite its importance to this extent, trust in family businesses is not studied thoroughly within the context of organizational relationships. Gagné et al. (2014) state that few studies in the context of family business have focused on trust and justice (p. 650). However, trust has a multifaceted and complicated structure; therefore, it should specifically be analyzed based on the relationship. Eddleston and Morgan (2014) note that trust, commitment and closely-knit relationships are critical for the sustainability of family businesses and they need to be studied from the perspective of processes, antecedents and consequences of phenomena.

Relationship between family members and non-family employees, which forms one of the characteristics of family businesses, is rather regarded as a potential of conflict; particularly nepotism is a cause of distrust by the non-family employees. However, family businesses also have strong and positive relationships. Especially in SMEs, some employees are as old as the history of the enterprise and have worked in harmony with members of several generations for a long time. This relationship is special and different from the relationship of the family with the other non-family members in the enterprise.

This study specifically focused on the trust relationship between the family members and the non-family employees working for a long time with at least two generations in small and medium sized enterprises. The sample of the research included ten SMEs and face-to-face interviews were held with the second-generation family members of these enterprises. The participants shared the perceptions of the family about the employees who have been working for a long time with the family. First of all, it can be claimed that the experiences are 
similar across the ten enterprises. It is noteworthy that although there is more than one non-family employee who has been working for minimum fifteen years, there are not so many of them who gain the whole trust of the family. There are only a few employees who are critically important to each enterprise and have become a part of the organizational culture. Family members explain their trust in these employees with competence, identification and personal trustworthiness.

It is remarkable that the competence of non-family employees has a content that is specific to the family business. These employees are not formally top managers. However, they have acquired a wide and flexible range of duties and responsibilities in time. These people are aware of things going on in the enterprise, observe the events and other employees, facilitate the work for the family, lead problem-solving processes. In brief, they are the hands of the family. They are cure-all men for the family. That is probably why the participants concentrated specifically on one of the longstanding employees during the interview.

Family members find these employees loyal and trustworthy on the basis of their observations and experiences in many years. They have tested their honesty, truthfulness and contentedness for many times. As they are trustworthy, these employees have a high personal reputation in the eye of the family members. This finding is consistent with the research findings of Ramos, Man, Mustafa, and $\mathrm{Ng}(2014$, p. 307) who argued that in small sized family businesses that provide long-term employment and security to their employees, such employees develop a strong sense of obligation and reciprocity towards the organization and the family rather than just doing what is written in their terms of reference. Their commitment has been defined in the literature as psychological ownership. Psychological ownership makes one feel as if s/he was the owner of a place and this feelings helps a person to express her/his own identity; it creates a sense of having a place (Pierce, Kostova, \& Dirks, 2001). Sieger et al. (2011) emphasize that long-term tenure enables long-standing employees to feel as if they were from the family, creates in-group perception and develops psychological ownership (p. 80). Addae-Boateng, Xiao, and Brew (2014) state that loyal employees commit themselves to the enterprise as if they were the owners and they stay with the enterprise through good times and through bad times even if their income is low (p. 16).

In addition, a human and social phenomenon, trust has culture-specific codes. Hofstede, Fritz, Canavari, Oosterkamp, and Sprundel (2010) conducted a study to develop a detailed trust typology and argued that trust is a culture-specific phenomenon because the societies are different from one another. Erdem and Aytemur (2014) conducted a study on the Turkish business organizations and demonstrated that the cultural tendencies in a trust relationship might change the expectations of parties. They found out that the dimensions of trust in the subordinates include competence and honesty. In fact, the dimensions of trust in the longstanding employees in family businesses also support those findings.

Turkey is among the societies with low social capital and low trust according to the results of some studies (Uğuz, Örselli, \& Sipahi, 2011). This means that trust is trapped within in-groups and trust relationship cannot be easily established with people outside the group. As a matter of fact, mutual trust and loyalty between the family members and non-family employees show that they are together forming an in-group. In addition, the fact that family members consider the non-family employees as part of the family also points to the creation of an in-group within business context. Furthermore, the studies regarding Turkish organizations have revealed strong evidence for paternalist leadership behavior (Aycan et al., 2000; Pasa, Kabasakal, \& Bodur, 2001; Berkman \& Ozen, 2008). The family members participating in our study also stated that they always protect the long-standing employees together with their families and pay close attention to them. This finding is consistent with benevolent paternalism expressed by Aycan et al. (2000) and Paşa et al. (2001). On the other hand, the fact that family members keep long-standing employees at their arm's length and do not maintain such relationship outside the enterprise is an indication of the perception of power distance. Turkey is among the countries that have high power distance (Hofstede, 1985; Berkman \& Ozen, 2008) and it is important to maintain vertical relationships and power distance in such cultures (Sargut, 2010).

In conclusion, even though this study had a small sample, it provides some clues that the trust relationship between the long-standing non-family members and the family members in family-owned SMEs is a special type of relationship. Yet, there are also some limitations in this study. Most importantly, the findings are limited to the perceptions of family members who participated in the study and the perceptions of non-family employees were not asked. This is a preliminary study and the authors are planning to analyze trust in further studies based on the perceptions of both parties. They think that both parties should confirm that trust is a mutual relationship.

Moreover, close trust relationship that makes the non-family employees perceived as if they were from the family is a more common phenomenon in small and medium sized enterprises, where the informal characteristic 
of trust relationship is more dominant. As the enterprise size gets larger and the number of outsiders increases, can it also develop a trust relationship with a similar content? This may be suggested as a research question. In the literature, it is known that stewardship theory focuses on outsider managers who are committed to the enterprise (Davis et al., 2000; Miller \& Miller, 2006; Blumentritt et al., 2007). Henssen et al. (2014) emphasize that in studies on family-owned businesses, it is a traditional trend to focus on loyal, committed and protective CEOs who display responsible behavior and altruism toward family members (p.216). However, stewards are not often top managers in small and medium sized enterprises. Therefore, if stewardship theory also focuses on the phenomenon of stewards specific to small and medium sized enterprises, it may provide original contributions to the literature on family-owned businesses.

Finally, it should also be noted that the trust relationship between the non-family employees themselves was not studied. In fact, this relationship may also create an interesting trust structure. Particularly whether the relationship between the longstanding employees (who are perceived by the family as deputies) and other non-family members creates a trust relationship or not may be an interesting research question. The following questions are worth studying: Does their affinity to the family weaken their relationships with the other employees? Or to what extent do the longstanding employees represent the non-family members before the family? If they assumed such catalyst role, would the trust perception of the family about the longstanding employees change? In conclusion, many behavioral questions concerning trust that are emphasized or could not be emphasized in this study are pending to be studied within the context of family-owned businesses. Particularly small and medium sized family-owned businesses have a rich relationship context. Thus, they offer valuable research opportunities to researchers of organizational behavior.

\section{References}

Addae-Boateng, S., Xiao, W., \& Brew, Y. (2014). Governance issues in family businesses: The views of family-member-employees, non-family-member-employees and management. International Journal of Economics, Commerce and Management, 2(12), 1-28.

Aycan, Z., Kanungo, R. N., Mendonca, M., Yu, K., Deller, J., Stahl, G., \& Khursid, A. (2000). Impact of culture on human resource management practices: A ten country comparison. Applied Psychology: An International Review, 49, 192-220. http://dx.doi.org/10.1111/1464-0597.00010

Bee, C., \& Neubaum, D. O. (2014). The role of cognitive appraisal and emotions of family members in the family business system. Journal of Family Business Strategy, 5(3), 323-333. http://dx.doi.org/10.1016/j.jfbs.2013.12.001

Berkman, Ü., \& Özen, Ş. (2008). Culture and management in Turkey: State-dependency and paternalism in transition. In: E. Davel, D. Jean-Pierre, \& C. Jean-François (Eds.), Gestion en contexte interculturel: Approches, problématiques, pratiques et plongées. Québec, Presse de l'Université Laval et Télé-université (UQAM).

Bhat, M. A., Shah, J. A., \& Baba, A. A. (2013). A literature study on family business management from 1990 to 2012. Journal of Business and Management, 7(6), 60-77.

Blumentritt, T. P., Keyt, A. D., \& Astrachan, J. H. (2007). Creating an environment for successful nonfamily CEOs: An exploratory study of good principals. Family Business Review, 20(4), 321-335. http://dx.doi.org/10.1111/j.1741-6248.2007.00102.x

Campopiano, G., De Massis, A., \& Chirico, F. (2014). Firm philanthropy in small- and medium-sized family firms: The effects of family involvement in ownership and management. Family Business Review, 27(3), 244-258. http://dx.doi.org/10.1177/0894486514538450

Carlock, R. S., \& Ward, J. L. (2001). Strategic planning for the family business. New York: Palgrave pub. http://dx.doi.org/10.1057/9780230508750

Davis, J., Schoorman, D., Mayer, R., \& Tan, H. (2000). The trusted general manager and business unit performance: Empirical evidence of a competitive advantage. Strategic Management Journal, 21, 563-576. http://dx.doi.org/10.1002/(SICI)1097-0266(200005)21:5<563::AID-SMJ99>3.0.CO;2-0

Eddleston, K. A., \& Morgan, R. M. (2014). Trust, commitment and relationships in family business: Challenging conventional wisdom. Journal of Family Business Strategy, 5(3), 213-216. http://dx.doi.org/10.1016/j.jfbs.2014.08.003

Eddleston, K. A., Chrisman, J. J., Steier, L. P., \& Chua, J. H. (2010). Governance and trust in family firms: An introduction. Entrepreneurship Theory and Practice, 34(6), 1043-1056. 
http://dx.doi.org/10.1111/j.1540-6520.2010.00412.x

Erdem, F., \& Aytemur, J. (2014). Context-specific dimensions of trust in manager, subordinate and co-worker in organizations. Journal of Arts \& Humanities, 3(4), 28-40.

Erdem, F., \& Özen, J. (2003). Cognitive and affective dimensions of trust in developing team performance. Team $\begin{array}{llll}\text { Performance Management: An International Journal, } & \text { 9(5/6) 131-135. }\end{array}$ http://dx.doi.org/10.1108/13527590310493846

Gagné, M., Sharma, P., \& De Massis, A. (2014). The study of organizational behaviour in family business. European Journal of Work and Organizational Psychology, 23(5), 643-656. http://dx.doi.org/10.1080/1359432X.2014.906403

Henssen, B., Voordeckers, W., Lambrechts, F., \& Koiranen, M. (2014). The CEO autonomy-stewardship behavior relationship in family firms: The mediating role of psychological ownership. Journal of Family Business Strategy, 5(3), 312-322. http://dx.doi.org/10.1016/j.jfbs.2014.01.012

Hofstede, G. (1985). The interaction between national and organizational value systems. Journal of Management Studies, 22(4), 347-357. http://dx.doi.org/10.1111/j.1467-6486.1985.tb00001.x

Hofstede, G., Fritz, M., Canavari, M., Oosterkamp, E., \& Sprundel, G. (2010). Towards a cross-cultural typology of trust in B2B food trade. British Food Journal, 112, 671-687. http://dx.doi.org/10.1108/00070701011058226

Jarvenpaa, S. L., Shaw, T. R., \& Staples, D. S. (2004). Toward contextualized theories of trust: The role of trust in global virtual teams. Information Systems Research, 15(3), 250-267. http://dx.doi.org/10.1287/isre.1040.0028

Jimenez, M. C. R., Martos, M. C. V., \& Jimenez, R. M. (2015). Organisational harmony as a value in family businesses and its influence on performance. Journal of Business Ethics, 126(2), 259-272. http://dx.doi.org/10.1007/s10551-013-1941-6

Jones, G. R., \& George, J. M. (1998). The experience and evolution of trust: Implications for cooperation and teamwork. Academy of Management Review, 23(3), 531-546.

Keleş, H. N., Özkan, T. K., \& Bezirci, M. (2011). A study on the effects of nepotism, favoritism and cronyism on organizational trust in the auditing process in family businesses in Turkey. International Business \& Economics Research Journal, 10(9), 9-16.

Kok, D. J., Uhlaner, L. M., \& Thurik, R. (2003). Human resource management with small firms: Facts and explanations. ERIM Report Series Reference No. ERS-2003-015-STR. Retrieved from http://papers.ssrn.com/sol3/papers.cfm?abstract_id=411655

Kramer, R. M. (1999). Trust and distrust in organizations: Emerging perspectives, enduring questions. Annual Review of Psychology, 50, 569-598. http://dx.doi.org/10.1146/annurev.psych.50.1.569

LaChapelle, K., \& Barnes, L. B. (1998). The trust catalyst in family-owned businesses. Family Business Review, 11(1), 1-17. http://dx.doi.org/10.1111/j.1741-6248.1998.00001.x

Lee, J. (2006). Family firm performance: Further evidence. Family Business Review, 19(3), 103-114. http://dx.doi.org/10.1111/j.1741-6248.2006.00060.x

Mayer, R. C., Davis, J. H., \& Schoorman, F. D. (1995). An integrative model of organizational trust. Academy of Management Review, 20(3), 709-734.

McAllister, D. J. (1995). Affect-and cognition-based trust as foundations for interpersonal cooperation in organizations. Academy of Management Journal, 38(1), 24-59. http://dx.doi.org/10.2307/256727

Miller, D., \& Miller, I. L. (2006). Family governance and firm performance: Agency, stewardship, and capabilities. Family Business Review, 19(1), 73-87. http://dx.doi.org/10.1111/j.1741-6248.2006.00063.x

Pasa, S. P., Kabasakal, H., \& Bodur, M. (2001). Society, organisations, and leadership in Turkey. Applied Psychology: An International Review, 50, 559-589. http://dx.doi.org/10.1111/1464-0597.00073

Pierce, J. L., Kostova, T., \& Dirks, K. T. (2001). Toward a theory of psychological ownership in organizations. The Academy of Management Review, 26(2), 298-310.

Rafaeli, A. (2013). Emotion in organizations: Considerations for family firms. Entrepreneurship Research Journal, 3(3), 295-300. http://dx.doi.org/10.1515/erj-2013-0061 
Ramos, H. M., Man, T. W., Mustafa, M., \& Ng, Z. Z. (2014). Psychological ownership in small family firms: Family and non-family employees' work attitudes and behaviours. Journal of Family Business Strategy, 5, 300-311. http://dx.doi.org/10.1016/j.jfbs.2014.04.001

Ribière, V. M., \& Sitar, A. S. (2010). The critical role of culture in knowledge management. In A. Green et al. (Eds.), Search of knowledge management: Pursuing primary principles. Pub: Emerald, Bingley.

Rousseau, D. M., Sitkin, S. B., Burt. R. S., \& Camerer, C. (1998). Not so different after all: A cross-discipline view of trust. Academy of Management Review, 23, 393-404. http://dx.doi.org/10.5465/AMR.1998.926617

Sargut, S. (2010). Kültürler Arası Farklılaşma ve Yönetim, İmge Yayınevi, Istanbul.

Sharma, P., \& Carney, M. (2012). Value creation and performance in private family firms: Measurement and methodological issues. Family Business Review, 25(3), 233-242. http://dx.doi.org/10.1177/0894486512457295

Sharma, P., Chrisman, J. J., \& Chua, J. H. (1997). Strategic management of the family business: Past research and future challenges. Family Business Review, 10(1), 1-35. http://dx.doi.org/10.1111/j.1741-6248.1997.00001.x

Sharma, P., Chua, J. H., \& Chrisman, J. J. (2000). Perceptions about the extent of succession planning in canadian family firms. Canadian Journal of Administrative Sciences, 17(3), 233-244. http://dx.doi.org/10.1111/j.1936-4490.2000.tb00223.x

Sieger, P., Bernhard, F., \& Frey, U. (2011). Affective commitment and job satisfaction among non-family employees: Investigating the roles of justice perceptions and psychological ownership. Journal of Family Business Strategy, 2(2), 78-89. http://dx.doi.org/10.1016/j.jfbs.2011.03.003

Sundaramurthy, C. (2008). Sustaining trust within family businesses. Family Business Review, 21(1), 89-102. http://dx.doi.org/10.1111/j.1741-6248.2007.00110.x

Uğuz, H., Örselli, E., \& Sipahi, E. B. (2011). Sosyal sermayenin ölçümü: Türkiye deneyimi. Akademik Incelemeler Dergisi, 6(1), 8-39.

Zellweger, T. M., \& Astrachan, J. H. (2008). On the emotional value of owning a firm. Family Business Review, 21(4), 347-363. http://dx.doi.org/10.1177/08944865080210040106

\section{Copyrights}

Copyright for this article is retained by the author(s), with first publication rights granted to the journal.

This is an open-access article distributed under the terms and conditions of the Creative Commons Attribution license (http://creativecommons.org/licenses/by/3.0/). 